\title{
Determination of the Partial Thermodynamic Functions for Sodium Bromide and Potassium Bromide in the Respective Bromide-Chloride Mixtures
}

\author{
TER JE ØSTVOLD
}

Institute of Physical Chemistry, The Technical University of Norway, Trondheim, Norway

\begin{abstract}
The partial free enthalpies of mixing of sodium bromide and potassium bromide in the sodium chloride-bromide and potassium chloridebromide mixtures, respectively, have been determined by electromotive force measurements on galvanic cells of the type

$\mathrm{Br}_{2}$ (g), (graphite) | Alk.Br(l) | Alk.glass | Alk.(Cl-Br)(l) | (graphite), $\mathrm{Br}_{2}(\mathrm{~g})$ where Alk. $=\mathrm{Na}$ or $\mathrm{K}$

Combining the excess partial free enthalpies of mixing from the present emf studies with calorimetric data on excess enthalpies, one can estimate the partial excess entropies for the alkali chloride. bromide mixtures. The excess partial entropies of mixing follows the equation:

$$
\Delta \bar{S}_{\text {Alk.Br }} \mathrm{E}=\alpha_{\text {Alk. }} \cdot x_{\text {Alk.C1 }}{ }^{2}
$$

The $\alpha$ values are found to be $\alpha_{\mathrm{Na}}=-0.23 \mathrm{cal} / \mathrm{mole}$ deg. and $\alpha_{\mathrm{K}}=-0.60 \mathrm{cal} / \mathrm{mole} \mathrm{deg}$.

These results indicate that the excess entropies are connected to next nearest neighbour interactions.
\end{abstract}

Thermodynamic studies of simple mixtures formed by the liquid alkali halides were performed by Kleppa and co-workers. ${ }^{1}$ The enthalpies of mixing of the binary halides were determined. So far there have been only a fow direct studies of the free energies of mixing of these compounds. Krohn and Moser ${ }^{2}$ used a formation cell of the type

$$
(\mathrm{Na}-\mathrm{Pb})(\mathrm{l})|(\mathrm{Na}-\mathrm{K}) \mathrm{Cl}(\mathrm{l})| \mathrm{Cl}_{2} \text { (g) }
$$

The partial free enthalpy of mixing of sodium chloride can be calculated from the difference in emf between a cell containing a sodium-potassium chloride mixture and a cell with pure sodium chloride.

In the present investigation the following cell was studied:

$$
\mathrm{Br}_{2}(\mathrm{~g}) \mid \text { Alk. } \mathrm{Br}(\mathrm{l}) \mid \text { Alk.glass } \mid \text { Alk. }(\mathrm{Br}, \mathrm{Cl})(\mathrm{l}) \mid \mathrm{Br}_{2}(\mathrm{~g})
$$

where Alk. = Na or $\mathrm{K}$.

Acta Chem. Scand. 22 (1968) No. 2 


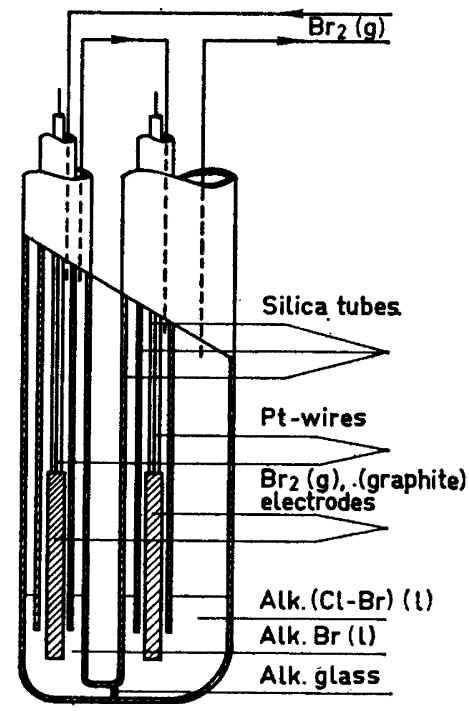

Fig. 1. The galvanic cell

$\mathrm{Br}_{2}(\mathrm{~g})$, (graphite) $\mid$ Alk.Br(l) $\mid$ Alk.glass $\mid$ Alk. $(\mathrm{Cl}-\mathrm{Br})(\mathrm{l}) \mid$ (graphite), $\mathrm{Br}_{2}(\mathrm{~g})$ where Alk. = Na or K.

The emf of this cell gives the partial free enthalpy of mixing of Alk.Br in the mixture Alk. $(\mathrm{Br}-\mathrm{Cl})$.

\section{EXPERIMENTAL}

The cell which is shown in Fig. 1 was made of quartz. Pieces of the glass which were used as the membrane, were melted in the quartz U-shaped tube to separate the two half cells. Composition of the glasses was

$\mathrm{Na}$-glass: 73 mole \% $\mathrm{SiO}_{2} 11$ mole $\% \mathrm{Al}_{2} \mathrm{O}_{3}, 16$ mole $\% \mathrm{Na}_{2} \mathrm{O}$

$$
\text { K-glass: } 69 " \%, " 5 " \%
$$

Both temperature and emf were recorded on a dual channel Philips recorder (PR 2212 $\mathrm{A} / 00$ ), which switched between emf and temperature recording automatically every 7 th minute. The resistance of the recorder was $10^{7} \mathrm{ohm}$, which is very high in comparison with a cell resistance of less than $1000 \mathrm{ohm}$. The cell potential was bucked by a potential from a zero suppressor (Reference Voltage Supply SINTEF 480140). This bucking potential was stable to $10^{-3} \%$. The resulting potential was then recorded, the full scale of the recorder being $20 \mathrm{mV}$ or $50 \mathrm{mV}$ depending on the stability and temperature variation of the potential. The recorder was regularly checked versus a Tinsley potentiometer. The same arrangement was used for the temperature measurements, the full scale of the recorder being $2 \mathrm{mV}$. With this arrangement the temperature could be determined with an accuracy of $\pm 1^{\circ} \mathrm{C}$, which was satisfactory for the present work. The accuracy of the recording instrument was better than the reproducibility of the measured potential.

The emf was determined as a function of composition and temperature. Alkali chloride crystals were added to the cell to change the composition. The temperature was changed stepwise and kept constant $\left( \pm 1^{\circ} \mathrm{C}\right)$ for an hour at each temperature. Then a sample was taken for analysis, and the temperature was changed. The amount of chloride and bromide was determined by potentiometric titration with silver nitrate. Samples had to be taken because the emf was slowly decreasing with time apparently due to change in composition of the electrolyte (see Fig. 2). The change in potential was small at low sodium chloride content, but significant at higher content (see Figs. 3 and 4). The equilibrium

$$
\mathrm{Alk} \cdot(\mathrm{Cl}, \mathrm{Br})(\mathrm{l})+\mathrm{Br}_{\mathbf{2}}(\mathrm{g}) \rightleftharpoons \mathrm{Alk} \cdot(\mathrm{Cl}, \mathrm{Br})(\mathrm{l})+\mathrm{BrCl}(\mathrm{g})
$$



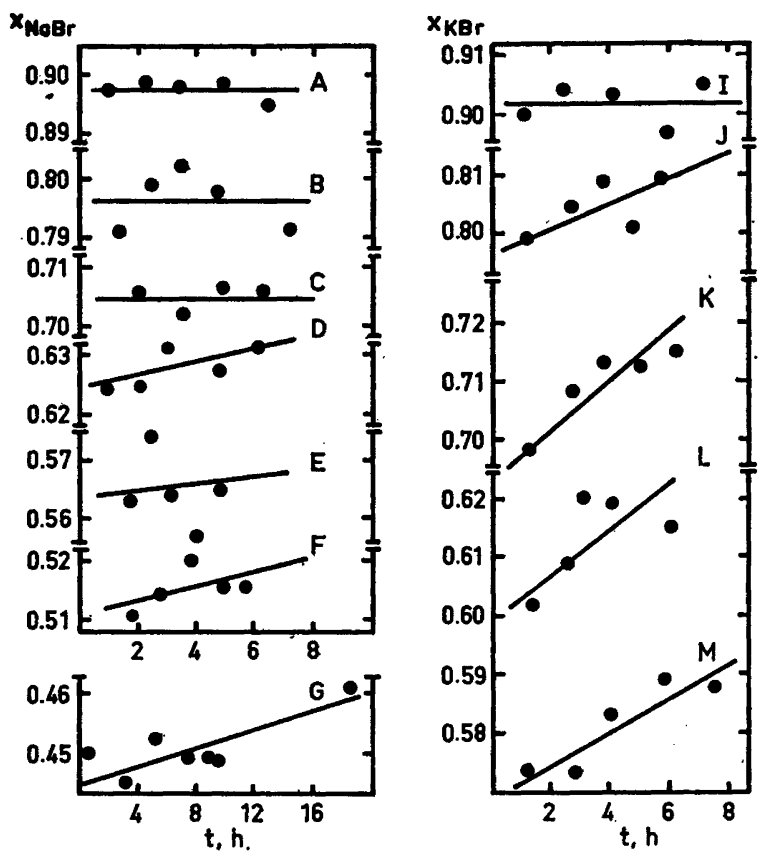

Fig. 2. The change in concentration of sodium bromide and potassium bromide, respectively, in the right part of the galvanic cell shown in Fig. 1. The letters refer to the experiment numbers given in Table 1 .

shows a significant pressure of bromine-chloride.

The constant stream of bromine gas through the system flushes out the brominechloride formed, and the composition changes. cell

Further experimental details are given by Frøyland et al..$^{3}$ who studied the galvanic

$$
\mathrm{Br}_{2}(\mathrm{~g}) \mid \text { Alk.Br(l) | Alk.glass | Alk.Cl(l) } \mid \mathrm{Cl}_{2}(\mathrm{~g})
$$

where Alk. is $\mathrm{Li}, \mathrm{Na}, \mathrm{K}$, or $\mathrm{Rb}$.

Influence of the above equilibrium on the emf measurements will be discussed later.

\section{RESULTS}

The emf, $E$, of the galvanic cell

$$
\mathrm{Br}_{2}(\mathrm{~g}) \mid \text { Alk.Br(l) } \mid \text { Alk.glass } \mid \text { Alk. }(\mathrm{Br}, \mathrm{Cl})(\mathrm{l}) \mid \mathrm{Br}_{2}(\mathrm{~g})
$$

is connected to the change in free enthalpy of the reaction

by the equation

$$
\text { Alk. } \operatorname{Br}(1)=\operatorname{Alk} \cdot \operatorname{Br}(1){ }_{(\text {in mixture })}
$$

$$
\Delta \bar{G}_{\mathrm{Alk} . \mathrm{Br}}=-n F E
$$

Acta Chem. Scand. 22 (1968) No. 2 

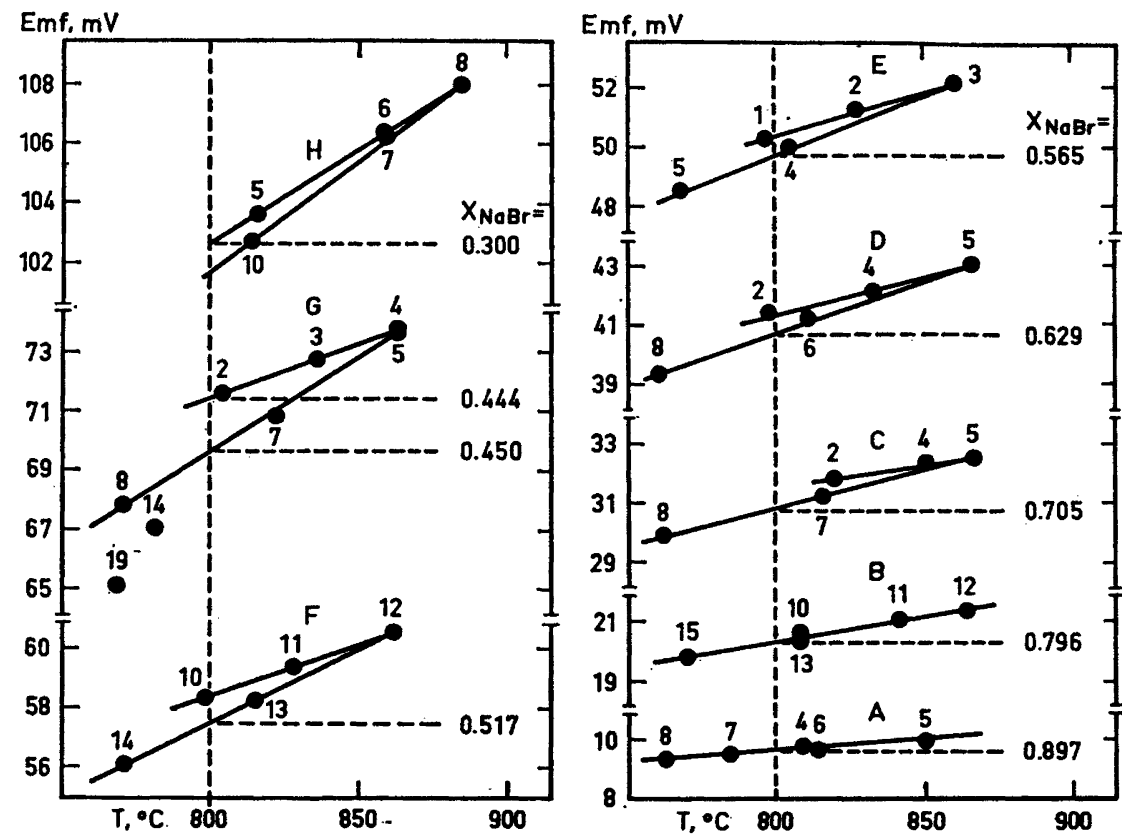

Fig. 3. Emf at different temperatures and concentrations for the galvanic cell $\mathrm{Br}_{2}(\mathrm{~g})|\mathrm{NaBr}(\mathrm{l})| \mathrm{Na}$-glass $|\mathrm{Na}(\mathrm{Br}-\mathrm{Cl})(\mathrm{l})| \mathrm{Br}_{2}(\mathrm{~g})$

The letters refer to the experiment numbers given in Table 1 and the numbers refer to hours after the experiment was started.

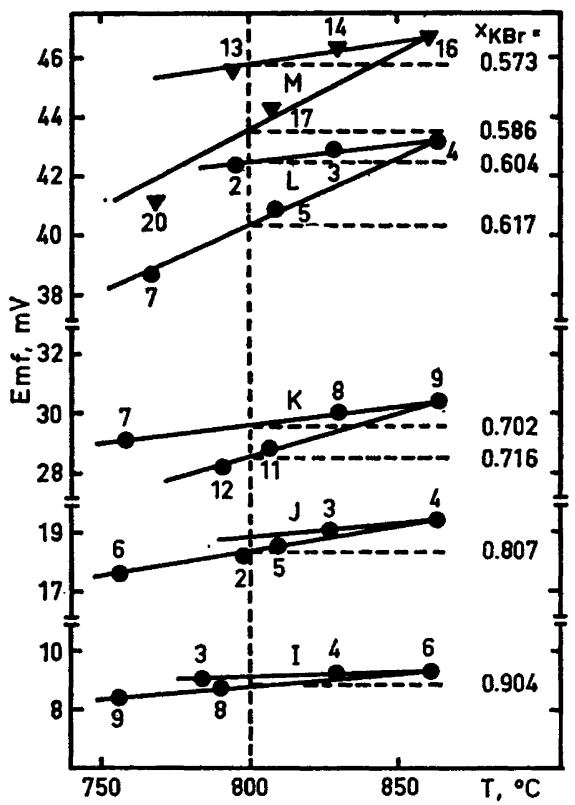

Fig. 4. Emf at different temperatures and concentrations for the galvanic cell $\mathrm{Br}_{2}(\mathrm{~g})|\mathrm{KBr}(\mathrm{l})| \mathrm{K}$-glass $|\mathrm{K}(\mathrm{Br}-\mathrm{Cl})(\mathrm{l})| \mathrm{Br}_{2}(\mathrm{~g})$ The letters refer to the experiment numbers given in Table 1 and the numbers refer to hours after the experiment was started.

Acta Chem. Scand. 22 (1968) No. 2 
Since the alkali ion is the only ion which transports electrical charge across the junction between the two half cells, no work is carried out in the junction, and there should be no correction for a liquid junction potential.

A summary of the results is given in Table 1. Figs. 5 and 6 are graphs of the excess partial free enthalpy and excess partial entropy of mixing as functions of composition.

Table 1. The excess partial free enthalpy and the excess partial entropy of mixing of sodium and potassium bromide in the sodium and potassium bromide-chloride mixtures, respectively, at $1073^{\circ} \mathrm{K} . \Delta \bar{G}^{* \mathrm{E}}$ given in column 4 is calculated by assuming equilibrium pressure of bromine chloride over the electrode dipping in the fused mixture.

1. Sodium chloride-sodium bromide mixtures.

\begin{tabular}{|c|c|c|c|c|}
\hline \multirow[t]{2}{*}{$\begin{array}{l}\text { Experiment } \\
\text { No. }\end{array}$} & \multirow{2}{*}{$\begin{array}{c}\text { Composition } \\
x \mathrm{NaBr}\end{array}$} & \multicolumn{2}{|c|}{$\begin{array}{l}\text { Excess partial free enthalpy } \\
\text { of mixing }\end{array}$} & \multirow{2}{*}{$\begin{array}{c}\text { Excess partial } \\
\text { entropy of mixing } \\
\Delta \overline{S_{\mathrm{NaBr}} \mathrm{E}} \text { cal/mole deg. }\end{array}$} \\
\hline & & $\Delta \bar{G}_{\mathrm{NaBr}} \mathrm{E}^{\mathrm{E}}$ & $\Delta \bar{G}_{\mathrm{NaBr}} * \mathrm{E}$ & \\
\hline & \multicolumn{4}{|c|}{ cal $/ \mathrm{mole}$} \\
\hline $\begin{array}{l}\mathbf{A} \\
\mathbf{B} \\
\mathbf{C} \\
\mathbf{D} \\
\mathbf{E} \\
\mathbf{F} \\
\mathbf{G} \\
\mathbf{H}\end{array}$ & $\begin{array}{l}0.897 \\
0.796 \\
0.705 \\
0.629 \\
0.565 \\
0.517 \\
0.45 \\
0.3\end{array}$ & $\begin{array}{r}10 \\
18 \\
35 \\
50 \\
69 \\
80 \\
100 \\
200\end{array}$ & $\begin{array}{r}0 \\
-3 \\
-1 \\
0 \\
4 \\
6 \\
5 \\
17\end{array}$ & $\begin{array}{l}-0.008 \\
-0.016 \\
-0.024 \\
-0.036 \\
-0.046 \\
-0.057 \\
-0.067 \\
-0.14\end{array}$ \\
\hline \multicolumn{5}{|c|}{ 2. Potassium chloride-potassium bromide mixtures. } \\
\hline $\begin{array}{l}\text { Experiment } \\
\text { No. }\end{array}$ & Composition & $\begin{array}{r}\text { Excess par } \\
-\quad 0\end{array}$ & $\begin{array}{l}\text { ee enthalpy } \\
\text { ag }\end{array}$ & $\begin{array}{l}\text { Excess partial } \\
\text { entropy of mixing }\end{array}$ \\
\hline & $x_{\mathrm{KBr}}$ & $\overline{\Delta \bar{G}_{\mathrm{KBr}} \mathrm{E}}$ & $\Delta \bar{G}_{\mathrm{KBr}} * \mathrm{E}$ & $\overline{\Delta S}{ }_{\mathrm{KBr}} \mathrm{cal} / \mathrm{mole} \mathrm{deg}$ \\
\hline & \multicolumn{4}{|c|}{ cal $/$ mole } \\
\hline $\begin{array}{l}\mathbf{I} \\
\mathbf{J} \\
\mathbf{K} \\
\mathbf{K} \\
\mathbf{L} \\
\mathbf{L} \\
\mathbf{M} \\
\mathbf{M}\end{array}$ & $\begin{array}{l}0.902 \\
0.807 \\
0.716 \\
0.702 \\
0.616 \\
0.604 \\
0.586 \\
0.573\end{array}$ & $\begin{array}{r}10 \\
30 \\
40 \\
72 \\
100 \\
90 \\
140 \\
130\end{array}$ & $\begin{array}{r}-\quad 6 \\
-\quad 4 \\
-19 \\
8 \\
8 \\
-\quad 7 \\
37 \\
22\end{array}$ & $\begin{array}{l}-0.014 \\
-0.037 \\
-0.052 \\
-0.052 \\
-0.075 \\
-0.075 \\
-0.119 \\
-0.119\end{array}$ \\
\hline
\end{tabular}

According to Temkin, 4 the partial free enthalpy of mixing of sodium bromide should be expressed as

$$
\Delta \bar{G}_{\mathrm{NaBr}^{\mathrm{id}}}=R T \ln x_{\mathrm{NaBr}}
$$

Differences between the experimental quantities and the quantities to be expected for ideal solutions (ideal Temkin mixtures) can be expressed by the excess partial free enthalpy of mixing

$$
\Delta \bar{G}_{\mathrm{NaBr}} \mathrm{E}=\Delta \bar{G}_{\mathrm{NaBr}(\mathrm{obs})}-\Delta \bar{G}_{\mathrm{NaBr}} \mathrm{id}
$$




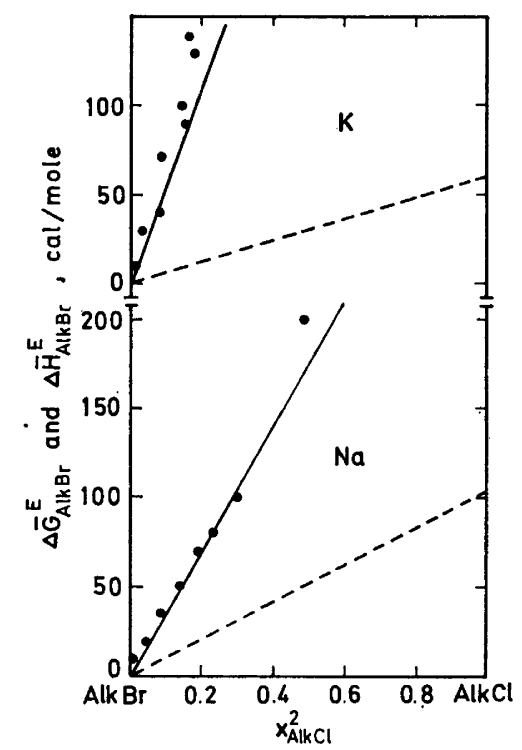

Fig. 5. Partial excess free enthalpies and partial excess enthalpies of mixing of sodium bromide and potassium bromide in the sodium and potassium chloride-bromide mixtures, respectively, at $1073^{\circ} \mathrm{K}$.

- $\overline{\Delta G}{ }_{\text {Alk.Br }}{ }^{\mathrm{E}}$ Present work. $-\Delta \bar{G}_{\mathrm{Alk} . \mathrm{Br}}{ }^{\mathrm{E}}$ Toguri et $a l .^{5}-\frac{-}{\text { et } a l^{6}} \Delta \bar{H}_{\mathrm{Alk.Br}} \mathrm{E}$ Kleppa

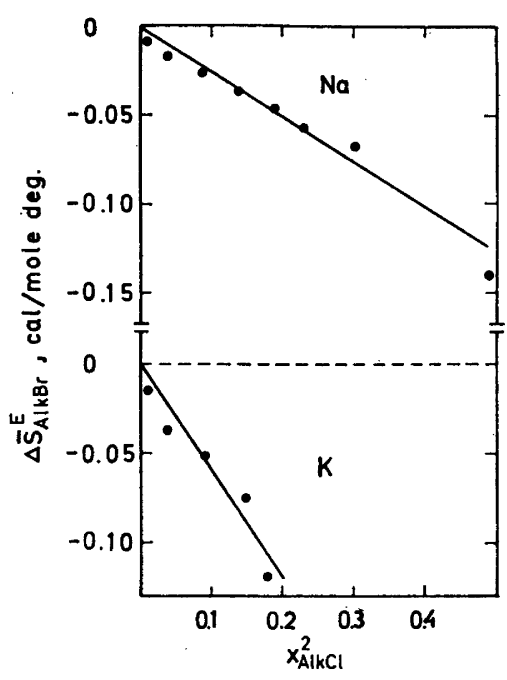

Fig. 6. Partial excess entropies of mixing of sodium bromide and potassium bromide in the sodium and potassium chloridebromide mixtures, respectively, at $1073^{\circ} \mathrm{K}$.

The excess partial entropy and the excess partial enthalpy of mixing are defined in an analogous way.

It can be seen from Fig. 5 that there is a fairly good agreement between the partial free enthalpies given in the present work and the values calculated from a work on chloride-bromide exchange equilibria by Toguri et al. ${ }^{5}$ The exchange measurements were carried out on mixtures of the halides, and the partial free enthalpy was obtained by extrapolation of the data for the exchange equilibrium and by assuming regular mixtures. It can further be seen that there is a marked difference between the excess partial free enthalpies and the partial enthalpies of mixing calculated from a work by Kleppa et al. ${ }^{6}$ This means that the entropy change on mixing deviates from ideality.

Equilibrium calculations on the exchange equilibrium

$$
\text { Alk. }(\mathrm{Cl}, \mathrm{Br})(\mathrm{l})+\mathrm{Br}_{2}(\mathrm{~g}) \rightleftharpoons \mathrm{Alk} \cdot(\mathrm{Cl}, \mathrm{Br})(\mathrm{l})+\mathrm{BrCl}(\mathrm{g})
$$

give bromine chloride partial pressures which are of the same order of magnitude as the bromine chloride pressures calculated from the loss of chloride from the fused mixture during the experiment. The equilibrium calculation is based on literature data of the $b$ values for the two binary alkali chloride- 
bromide mixtures: ${ }^{5} b_{\mathrm{Na}}=350 \mathrm{cal} / \mathrm{mole}, b_{\mathrm{K}}=530 \mathrm{cal} / \mathrm{mole}$ and on the literature data on the two following equilibria:

$$
\begin{aligned}
\mathrm{Alk} \cdot \mathrm{Cl}(\mathrm{l})+\frac{1}{2} \mathrm{Br}_{2}(\mathrm{~g}) & \rightleftharpoons \mathrm{Alk} \cdot \mathrm{Br}(\mathrm{l})+\frac{1}{2} \mathrm{Cl}_{2}(\mathrm{~g}) \\
\frac{1}{2} \mathrm{Cl}_{2}+\frac{1}{2} \mathrm{Br}_{2}(\mathrm{~g}) & \rightleftharpoons \mathrm{BrCl}(\mathrm{g})
\end{aligned}
$$

where $\Delta G_{\mathrm{Na}}{ }^{\circ}=7280 \mathrm{cal} / \mathrm{mole},{ }^{3} \Delta G_{\mathrm{K}}{ }^{\circ}=6140 \mathrm{cal} / \mathrm{mole},{ }^{3}$ and $\Delta G_{\mathrm{BrCl}}{ }^{\circ}=-1720$ cal $/$ mole. $^{7}$

If these bromine chloride pressures are used to correct for the fact that the bromine electrode does not function as an ideal bromine electrode in the fused mixtures, the following equation is obtained for the excess partial free enthalpy of mixing of the alkali bromide:

$$
\Delta{\overline{G_{\mathrm{Alk} . \mathrm{Br}}}}^{* \mathrm{E}}=-n F E+\frac{1}{2} R T \ln p_{\mathrm{Br}_{2}} / p_{\mathrm{Br}_{2}}^{\circ}
$$

where $p_{\mathrm{Br}_{2}}$ is the calculated equilibrium pressure of bromine over the fused mixture, and $p_{\mathrm{Br}_{2}}{ }^{\circ}(1 \mathrm{~atm}$.) is the pressure of bromine over the electrode dipping in the pure fused alkali bromide.

The agreement between the excess partial free enthalpies of mixing of the two alkali bromides based on the above equilibrium calculation and the data of Toguri et al..$^{5}$ is not as good as the agreement between the excess partial free enthalpies of mixing based on the assumption of ideal bromine electrodes and the values reported by Toguri et al. The modification, however, of the excess partial free enthalpies of mixing given by the above equation is in the direction of the values of Toguri et al.

It is therefore reasonable to assume that the bromine electrode in the fused mixtures of sodium chloride-bromide and potassium chloride-bromide will function very closely as an ideal bromine electrode when the bromide content is more than 50 mole $\%$ in the potassium mixtures and more than 30 mole $\%$ in the sodium mixtures.

\section{DISCUSSION}

When calculating the entropy of mixing for a binary system it is common to use a lattice model and to consider the configurational entropy only. In a binary system $\mathrm{AD}-\mathrm{AC}\left(\mathrm{A}^{+}\right.$forming the cation and $\mathrm{D}^{-}$and $\mathrm{C}^{-}$forming the anions) where deviation from random distribution is considered, the excess partial molar entropy of one component (for example AD) is

$$
\Delta \bar{S}_{\mathrm{AD}}^{\mathrm{E}}=x_{\mathrm{D}} x_{\mathrm{C}^{2}}\left(1-3 x_{\mathrm{C}}\right) \frac{E^{2}}{Z R T^{2}}
$$

where $x_{\mathrm{D}}$ and $x_{\mathrm{C}}$ are the molar fractions of $\mathrm{AD}$ and $\mathrm{AC}$, respectively. $Z$ is the number of anions surrounding any anion in the second coordination shell, and $E$ is the change in energy due to next nearest neighbours when one mole of $\mathrm{AD}$ is dissolved in a large quantity of $\mathrm{AC}$ (see Førland ${ }^{8}$ ).

If eqn. ( 1 is used to calculate the excess partial entropy of mixing of sodium bromide and potassium bromide in the sodium and potassium chloridebromide mixtures, respectively, $\Delta \bar{S}_{\mathrm{Alk} . \mathrm{Br}}{ }^{\mathrm{E}}$ is found to be $\simeq 10^{-2} \mathrm{cal} / \mathrm{mole}$ deg., which differs markedly from the values presented in Fig. 6.

Acta Chem. Scand. 22 (1968) No. 2 
However, Kleppa et al. ${ }^{9}$ and Førland ${ }^{10}$ suggested an expression of the type

$$
\Delta S^{\mathrm{E}}=\alpha x(1-x)
$$

for the concentration dependence of the excess molar entropy of mixing. Experimental verification of eqn. (2) is found in the $(\mathrm{Ag}-\mathrm{Alk}) \mathrm{NO}_{3}$ mixtures by Ketelaar et al..$^{11}$ who measured the partial free enthalpy of mixing of silver nitrate in the mixtures with the alkali nitrates. The free enthalpy data were combined with the heat of mixing data for the same systems measured by Kleppa et al.,9 giving the excess entropies of mixing in Table 2.

Table $2 . \alpha$ for binary mixtures of silver nitrate and alkali nitrate given by Ketelaar et al. ${ }^{11}$ at $350^{\circ} \mathrm{C}$.

System investigated

$$
\begin{aligned}
& \mathrm{AgNO}_{3}-\mathrm{LiNO}_{3} \\
& \mathrm{AgNO}_{3}-\mathrm{NaNO}_{3} \\
& \mathrm{AgNO}_{3}-\mathrm{KNO}_{3} \\
& \mathrm{AgNO}_{3}-\mathrm{RbNO}_{3} \\
& \mathrm{AgNO}_{3}-\mathrm{CsNO}_{3}
\end{aligned}
$$

$$
\begin{gathered}
\alpha, \text { cal } / \text { mole deg. } \\
\\
-0.37 \pm 0.08 \\
-0.64 \pm 0.12 \\
-0.35 \pm 0.15 \\
-0.80 \pm 0.23 \\
-0.61 \pm 0.21
\end{gathered}
$$

Frøyland et al..$^{3}$ found that the entropy change for reciprocal reactions of the type

$$
\mathrm{Alk}_{\cdot} \mathrm{Br}(\mathrm{l})+\mathrm{Alk}_{\cdot_{2}} \mathrm{Cl}(\mathrm{l})=\mathrm{Alk}_{{ }_{1}} \mathrm{Cl}(\mathrm{l})+\mathrm{Alk}_{{ }_{2}} \mathrm{Br}(\mathrm{l})
$$

was considerable.

When calculating the entropy of mixing for a system containing a mixture of the four salts in reaction (3), it is common to consider the configurational entropy only. The significant entropy change for reaction (3) shows, however, that other contributions to the entropy of mixing have to be taken into account in a more thorough calculation. Førland ${ }^{10}$ has proposed a model for describing the excess entropy change on mixing. Førland assumes that the excess entropy can be attributed to changes in the vibrational entropy created by the change in the environment of the ions by the mixing process. The vibrational entropy can be expressed as a sum of terms assigned to pairs of cations and anions. For a binary system $\mathrm{AD}-\mathrm{AC}\left(\mathrm{A}^{+}\right.$forming the cation and $\mathrm{D}^{-}$and $\mathrm{C}^{-}$forming the anions) the vibrational entropy of mixing should accordingly be

$$
\Delta S_{\mathrm{vibr}}=\frac{1}{2}\left\{\left(n_{\mathrm{D}}+n_{\mathrm{C}}\right)\left(x_{\mathrm{D}}{ }^{2} S_{\mathrm{D}-\mathrm{D}}{ }^{\prime}+2 x_{\mathrm{D}} x_{\mathrm{C}} S_{\mathrm{D}-\mathrm{C}^{\prime}}+x_{\mathrm{c}}{ }^{2} S_{\mathrm{C}-\mathrm{C}^{\prime}}\right)-n_{\mathrm{D}} S_{\mathrm{D}-\mathrm{D}}{ }^{\prime}-n_{\mathrm{C}} S_{\mathrm{C}-\mathrm{C}^{\prime}}\right\}
$$

where $S_{\mathrm{D}-\mathrm{D}}$ is the contribution to the vibrational entropy due to $\mathrm{D}-\mathrm{D}$ interactions. Differentiating this equation with respect to the $A D$ content and choosing pure $\mathrm{AD}$ as the standard state, one obtains the partial molar vibrational entropy of mixing of $\mathrm{AD}$

$$
\Delta \bar{S}_{\mathrm{AD}(\mathrm{vibr})}=x_{\mathrm{c}}{ }^{2} \frac{1}{2}\left(2 S_{\mathrm{D}-\mathrm{C}^{\prime}}-S_{\mathrm{D}-\mathrm{D}}{ }^{\prime}-S_{\mathrm{C}-\mathrm{C}^{\prime}}\right)=x_{\mathrm{c}}{ }^{2} S_{\mathrm{A}}
$$

where $S_{\mathrm{A}}$ is a constant. 
In Fig. 6 the excess partial entropy of mixing of sodium bromide and potassium bromide are plotted as a function of $x_{\mathrm{cl}}{ }^{2}$. It can be seen from Fig. 6 that the experimental values form straight lines. The slope of the plot of the excess partial entropy as a function of $x_{\mathrm{cl}}{ }^{2}$ is given in Table 3. The same data can also be obtained from a combination of the excess partial free enthalpy

Table 3. $\alpha$ for binary mixtures of alkali chloride and alkali bromide at $1073^{\circ} \mathrm{K}$.

$\begin{array}{lcc}\text { System investigated } & \begin{array}{c}\text { This work } \\ \alpha, \text { cal/mole deg. }\end{array} & \begin{array}{c}\text { Toguri et al. } \\ \alpha, \text { cal/mole deg. }\end{array} \\ \mathrm{LiCl}-\mathrm{LiBr} & & -0.09 \\ \mathrm{NaCl}-\mathrm{NaBr} & -0.23 & -0.23 \\ \mathrm{KCl}-\mathrm{KBr} & -0.60 & -0.44\end{array}$

of mixing of alkali bromide in a mixture with the same alkali chloride, obtained from exchange equilibria by Toguri et al. ${ }^{5}$ and the partial heat of mixing of the alkali bromide in the chloride bromide mixtures, given by Kleppa et al. ${ }^{6}$ (see Table 3).

The difference between the results obtained by Toguri et al. ${ }^{5}$ and the results of the present investigation for the potassium chloride-potassium bromide mixture is probably due to the fact that bromine chloride gas is formed when bromine gas is bubbled through the fused mixture.

Acknowledgement. Gratitude is expressed to professor Tormod Førland and professor Hakon Flood for their kind help and interest, and to Norges Teknisk-Naturvitenskapelige Forskningsråd for financial support.

\section{REFERENCES}

1. Kleppa, O. J. and Hersh, L. S. J. Chem. Phys. 42 (1965) 1309.

2. Krohn, C. H. and Moser, Z. To be published.

3. Frøyland, et al. In Førland, T., Grjotheim, K., Motzfeldt, K. and Urnes, S. Selected Topics in High Temperature Chemistry, Universitetsforlaget, Oslo 1966, p. 27.

4. Temkin, H. Acta physicochim. URSS 20 (1945) 411.

5. Toguri, J., Flood, H. and Forland, T. Acta Chem. Scand. 17 (1963) 1502.

6. Kleppa, O. J., Hersh, L. S. and Toguri, J. Acta Chem. Scand. 17 (1963) 2681.

7. Janaf Thermochemical Data, The Dow Chemical Company, Midland, Michigan 1962.

8. Førland, T. In Sundheim, B. R. Fused Salts, McGraw, New York 1964, p. 88.

9. Kleppa, O. J. and Hersh, L. S. J. Chem. Phys. 35 (1961) 175.

10. Førland, T. Discussions Faraday Soc. 32 (1962) 122.

11. Ketelaar, J. A. A. and Dammers-De Klerk, A. Koninkl. Ned. Akad. Wetenschap. Proc., Ser. $B 68$ (1965) 169, No. 4.

Received May 29, 1967. 